\title{
No Way Out: Eighth Amendment Protection for Do-Or-Die Acts of the Homeless
}

\author{
Edward J. Walters $\dagger$
}

The Supreme Court held in its 1962 decision Robinson $v$ California that it was cruel and unusual under the Eighth Amendment to punish people for "status" crimes - that is, crimes defined by who people are, not what they do. ${ }^{1}$ In the decade following that decision, courts used the status crimes doctrine to invalidate statutes that made vagrancy illegal. ${ }^{2}$ In response to recent, explosive increases in their homeless populations, however, many communities have bypassed the Court's status crimes mandate by outlawing actions that are attendant to vagrancy, such as sleeping in public places. Homeless people in these communities have used the status crimes doctrine to challenge such ordinances; however, since the Supreme Court narrowed the doctrine in Powell $v$ Texas, ${ }^{3}$ the Eighth Amendment has provided the homeless with very precarious protection.

A plurality of the Powell Court withdrew Robinson's protection of acts attendant to status, even where punishment of such acts has the practical consequence of proscribing the status itself. Whereas Robinson held that it was cruel and unusual to punish status, Powell implied that states could punish status, so long as

$\dagger$ A.B. 1992, Georgetown University; J.D. Candidate 1996, The University of Chicago.

1370 US 660, 666-67 (1962). The Eighth Amendment protection was extended to Robinson by operation of the Fourteenth Amendment, which prevents states from intruding upon constitutional rights of individuals. Although the Court had previously suggested that the Eighth Amendment might be extended to the states, Francis $v$ Resweber, 329 US 459, 463 (1947), the first application of the Eighth Amendment to block state action was in Robinson. Even before the Supreme Court extended the Eighth Amendment's operation to the states, some state constitutions had incorporated parallel protection against cruel and unusual punishment. See Benjamin S. Waxman, Fighting the Criminalization of Homelessness: Anatomy of an Institutional Anti-Homeless Lawsuit, 23 Stetson L Rev 467, 484 n 82 (1994). Contemporary courts have interpreted some state guarantees to offer more protection than the Eighth Amendment. See, for example, Tillman $v$ State, 591 S2d 167, 169 n 2 (Fla 1991) (interpreting Fla Const, Art I, § 17).

${ }^{2}$ See, for example, Wheeler $v$ Goodman, 306 F Supp 58, 62 (W D NC 1969) (striking law that punished low economic status); Decker v Fillis, 306 F Supp 613, 617 (D Utah 1969) (same).

3392 US 514, 533 (1968). 
they did so under the pretext of punishing some act. The status crimes doctrine, said the Powell Court, did not protect acts.

This Comment addresses two distinct theories in the context of homelessness and attendant conduct: the status crimes doctrine and a more direct application of the Eighth Amendment's prohibition of cruel and unusual punishment. First, this Comment reaffirms that the status crimes doctrine protects at least the status of homelessness, as well as many acts attendant to that status. Justice White's swing-vote concurrence in Powell explicitly stated that the holding did not apply to homeless people. Second, this Comment suggests that although plaintiffs in these cases might win on their status crimes argument, they may be barking up the wrong Eighth Amendment tree. The Eighth Amendment prohibition of cruel and unusual punishment directly forbids communities from criminalizing certain aspects of homelessness. When cities prohibit life-sustaining conduct, they present people with an unconstitutional mandate: follow the law and die, or stay alive and risk arrest. This Comment proposes that courts must invalidate statutes that offer people no lawful choice but death, because punishing truly life-sustaining conduct is per se cruel and unusual. Thus, homeless people may, but need not resort to the status crimes doctrine.

Part I of this Comment addresses the status crimes doctrine and concludes that at least some acts of the homeless are protected under it. Part I begins by discussing the two Supreme Court cases that define status crimes. It then criticizes the Supreme Court's narrowing of the status crimes doctrine and demonstrates that a majority of the narrowing Court (four dissenters and one concurring Justice) would not apply the more narrow construction to homelessness cases. Part I concludes with an analysis of recent cases in which plaintiffs have claimed Eighth Amendment protection for prohibited conduct necessitated by homelessness. This analysis demonstrates the difficulty lower courts have experienced in applying the Supreme Court's status crimes doctrine to this conduct-focused class of homelessness cases. It also asserts that the status crimes doctrine, properly read, forbids many of the ordinances involved in these cases.

Part II suggests that the Eighth Amendment prohibition of cruel and unusual punishment directly forbids lawmakers from punishing homeless people for do-or-die acts. It begins by proposing that a city may prohibit acts of the homeless only if it can show that homeless people have a lawful alternative (death does not count as an alternative). This Part then offers a guide to 
cities wishing to exercise their police power in a manner consistent with the Eighth Amendment. Part II concludes with an analysis of pending cases in light of a full understanding of the status crimes doctrine and the guarantees of the Eighth Amendment. $^{4}$

\section{The Status CRIMES DoCTRINe}

The Supreme Court has held that punishing a person for her status is cruel and unusual under the Eighth Amendment. ${ }^{5}$ In Robinson $v$ California, the Court held that a statute prohibiting the status of drug addiction was unconstitutional. ${ }^{6}$ Six years later, however, in Powell v Texas, a plurality of the Court upheld a statute prohibiting intoxication in a public place. ${ }^{7}$ The Powell Court's refusal to apply the status crimes doctrine to facts seemingly similar to those in Robinson has made faithful interpretation of the doctrine a difficult enterprise for lower courts.

\section{A. The Status Crimes Doctrine in the Supreme Court}

\section{Robinson v California.}

The flagship case in status crimes doctrine is Robinson $v$ California. In that case, the Supreme Court invalidated a California statute that criminalized drug addiction. ${ }^{8}$ The Court said that punishing a status in the absence of a criminal act was per se cruel and unusual and thus violated the Eighth Amendment. ${ }^{9}$

4 Plaintiffs in these recent homelessness cases have sued on various grounds with mixed success. These include violation of civil rights, overbreadth, discriminatory application of the law, and violation of the right to travel. See, for example, Tobe $v$ City of Santa Ana, 9 Cal 4th 1069, 40 Cal Rptr 2d 402, 409 (1995). This Comment will not address any of these collateral issues. It will only address challenges alleging that ordinances are unconstitutional as applied under the Eighth Amendment.

- The Eighth Amendment states, "Excessive bail shall not be required, nor excessive fines imposed, nor cruel and unusual punishments inflicted." US Const, Amend VIII.

370 US at 667.

7392 US at 534-35.

B Robinson, 370 US at 667 . The statute in question was $\$ 11721$ of the California Health and Safety Code. It provided, in part, that:

[n]o person shall use, or be under the influence of, or be addicted to the use of narcotics, excepting when administered by or under the direction of a person licensed by the State. . . Any person convicted of violating any provision of this section is guilty of a misdemeanor and shall be sentenced to serve a term of not less than 90 days nor more than one year in the county jail.

Id at $660 \mathrm{n} 1$ (emphasis added), quoting Cal Health and Safety Code $\$ 11721$ (West 1964).

- Robinson, 370 US at 667. 
In Robinson, a Los Angeles police officer arrested the defendant on the street one evening after noticing track marks on the defendant's arm. ${ }^{10}$ During questioning Robinson admitted to the occasional use of narcotics. ${ }^{11}$ Although the police had evidence that he had used drugs in Los Angeles and could have prosecuted Robinson for such use, they chose instead to prosecute him under a California statute that criminalized drug addiction. ${ }^{12}$

The Supreme Court reversed Robinson's conviction, basing its decision both on the fact that a drug addiction could be acquired without a culpable choice and on the fact that no act was involved in his alleged crime. ${ }^{13}$ Justice Stewart, writing for a six-Justice majority, compared the status of drug addiction to physical illness, both of which could be acquired "innocently or involuntarily":

It is unlikely that any State at this moment in history would attempt to make it a criminal offense for a person to be mentally ill, or a leper, or to be afflicted with a venereal disease .... [I]n the light of contemporary human knowledge, a law which made a criminal offense of such a disease would doubtless be universally thought to be an infliction of cruel and unusual punishment in violation of the Eighth and Fourteenth Amendments.... We cannot but consider the statute before us as of the same category. In this Court counsel for the State recognized that narcotic addiction is an illness. Indeed, it is apparently an illness which may be contracted innocently or involuntarily. We hold that a state law which imprisons a person thus afflicted as a criminal, even though he has never touched any narcotic drug within the State or been guilty of any irregular behavior there, inflicts a cruel and unusual punishment in violation of the Fourteenth Amendment. ${ }^{14}$

The Court emphasized that a person may become an addict innocently, without a culpable act or choice, by being born addicted or

10 Id at 661.

11 Id.

12 Id at 664-65. The judge in the lower court instructed the jury that Robinson could be convicted if he had committed an act prohibited by the statute or if he "was" of a prohibited status: "All that the People must show is either that the defendant did use a narcotic in Los Angeles County, or that while in the City of Los Angeles he was addicted to the use of narcotics ...." Id at 663 .

13 Id at 666-67.

14 Id at 667. 
becoming addicted to lawfully prescribed medication. ${ }^{15}$ But the majority also said that the California statute was unconstitutional because it criminalized people for who they were, and not for any criminal act:

[W]e deal with a statute which makes the "status" of narcotic addiction a criminal offense, for which the offender may be prosecuted "at any time before he reforms." California has said that a person can be continuously guilty of this offense, whether or not he has ever used or possessed any narcotics within the State, and whether or not he has been guilty of any antisocial behavior there. ${ }^{16}$

Justice Stewart thus seemed to base the Court's holding on two findings: that the California law punished a status that might be contracted nonculpably, and that there was no act involved in the alleged crime (because Robinson was not prosecuted for the act of shooting up). ${ }^{17}$

In a dissenting opinion, Justice White criticized the majority for not recognizing the actions inherent in the status of drug addiction. According to White, the status of addiction should not be protected because the defendant had caused his own condition by taking drugs. ${ }^{18}$ Justice White characterized Robinson's arrest as punishing the act of using narcotics, not the status of addiction. ${ }^{19}$ White pointed out that the status of addiction was defined at trial as "the regular use of narcotics," and that the reason California punished addiction itself was to supersede its venue requirements in cases where there was no evidence of the county in which the defendant had actually used drugs. ${ }^{20}$ In addition, Justice White pointed out that evidence showed needle marks as recent as three to ten days old, and that Robinson had used narcotics at least seven times in the fifteen days before his arrest. ${ }^{21}$ Recognizing that under the majority's reasoning, status protection could logically be extended to protect acts attendant to status, Justice White concluded that if the Court protected the status of addiction, it might also have to extend Eighth Amendment protection to the use of drugs on the same evidence

1s Id at $667 \mathrm{n} 9$.

16 Id at 666.

17 Id at 667 .

18 Id at 686 (White dissenting).

19 Id.

20 Id at 686-87.

21 Id at $686 \mathrm{n} 3$. 
used to show that defendant was an addict-a slippery slope Justice White was unwilling to descend. ${ }^{22}$

Justice White's dissent notwithstanding, Robinson clearly invalidated vagrancy statutes in every state of the union. Such statutes punished general aimlessness and unemployment, ${ }^{23}$ which were definitions of people's statuses, not culpable actions. Such laws thus fell squarely within Robinson's status crimes doctrine. Indeed, courts struck down vagrancy statutes in the 1960 s and 1970s on a number of constitutional grounds, ${ }^{24}$ including the status crimes doctrine.

\section{Powell v Texas.}

Some of the protections afforded by Robinson were shortlived. In Powell $v$ Texas, the Court both elaborated on and obscured the definition of status crimes by affirming the conviction of a chronic alcoholic for being drunk in public. ${ }^{25}$ Writing for a four-Justice plurality, Justice Marshall distinguished Robinson, holding that Powell was arrested for the actions of drinking, venturing out into the public, and creating health and safety hazards, not for the status of being an alcoholic. ${ }^{26}$ The Court departed from the practice of the Robinson Court by upholding the statute, which plainly authorized punishment for mere status (although Powell was convicted for an act). The plurality also ignored the culpability reasoning of Robinson, instead relying solely on the fact that drinking and appearing in public were cognizable acts that satisfied the common law actus reus requirement:

22 Id at 688-89.

23 See, for example, District of Columbia $v$ Hunt, 163 F2d 833, 835 (DC Cir 1947) ("A vagrant is a probable criminal; and the purpose of the statute is to prevent crimes which may likely flow from his mode of life."), quoted in Harry Simon, Towns Without Pity: A Constitutional and Historical Analysis of Official Efforts to Drive Homeless Persons from American Cities, 66 Tulane L Rev 631, 640 (1992).

${ }^{24}$ Simon, 66 Tulane L Rev at 642-43 \& n 77 (cited in note 23), citing People v Berck, 32 NY2d 567, 347 NYS2d 33, 300 NE2d 411, 415 (1973) (loitering statute violated Privileges and Immunities Clause); Hayes $v$ Municipal Court of Oklahoma City, 487 P2d 974, 979 (Okla 1971) (ordinance violated "constitutionally guaranteed freedom of movement"); City of Portland $v$ James, 251 Or 8, 444 P2d 554, 557-58 (1968) (vagueness); Decker $v$ Fillis, 306 F Supp 613, 617 (D Utah 1969) (overbreadth and impermissible chilling of liberty of "presence and physical status").

${ }^{25} 392$ US at 535-36. The relevant Texas statute made it illegal for a person to "get drunk or be found in a state of intoxication in any public place, or at any private house except his own." Tex Penal Code Ann $\$ 477$ (Vernon 1952) (emphasis added).

${ }_{26}$ Powell, 392 US at 532. 
The entire thrust of Robinson's interpretation of the Cruel and Unusual Punishment Clause is that criminal penalties may be inflicted only if the accused has committed some act, has engaged in some behavior, which society has an interest in preventing, or perhaps in historical common law terms, has committed some actus reus. ${ }^{27}$

The Powell plurality thus created a simple "act-excluding" test for status crimes: if the defendant committed an act, even one so unobtrusive as going outside, that defendant forfeited any Eighth Amendment protection under Robinson's status crimes doctrine.

However, a majority of the Court-four dissenting Justices and one concurring Justice-rejected the plurality's reading of Robinson. Justice Fortas dissented in Powell, pointing out that the Texas statute punished 'being in a state of intoxication' in public, ${ }^{228}$ which was no less a status crime than being a drug addict was in Robinson. Fortas and three other Justices suggested that the addition of a location element to the offense did not change the fact that the statute was punishing status because it punished Powell for "being in a condition which he had no capacity to change or avoid..29 In contrast to the result of the plurality's act-excluding test, Fortas suggested that to punish Powell was unconstitutionally cruel because Powell's presence in public was beyond his control. ${ }^{30}$ In other words, Powell, a chronic alcoholic, had not made a culpable choice to commit the offense.

Fortas and the dissenting Justices focused on the volitional language of Robinson, arguing that Powell was punished for an act that he was "utterly powerless to avoid," one that derived directly from his noncriminal status as a chronic alcoholic. ${ }^{31}$ The dissent asserted that the Eighth Amendment protected "compelled" acts that one could not help but choose: "Criminal penalties may not be inflicted upon a person for being in a condition he is powerless to change. ${ }^{.32}$ The dissenting Justices thus conceded that Powell may have acted, but argued that because he was unable to do otherwise, it was cruel and unusual to punish him.

\footnotetext{
27 Id at 533.

${ }^{28}$ Id at 558 (Fortas dissenting).

$\approx$ Id at 567 .

30 Id.

31 Id.

32 Id.
} 
Justice White did not join in the plurality opinion, but concurred in the result because he found no evidence that Powell's status as a drunk person forced him to appear in public. ${ }^{33}$ To illustrate his point, White suggested that a person who got drunk and had no home in which to stay might be forced to be in public. In that case, he said, the ordinance would really be punishing drinking, an act not prohibited by law:

The fact remains that some chronic alcoholics must drink and hence must drink somewhere. Although many chronics have homes, many others do not. For all practical purposes the public streets may be home for these unfortunates, not because their disease compels them to be there, but because, drunk or sober, they have no place else to go and no place else to be when they are drinking .... For some of these alcoholics I would think a showing could be made that resisting drunkenness is impossible and that avoiding public places when intoxicated is also impossible. As applied to them this statute is in effect a law which bans a single act for which they may not be convicted under the Eighth Amendment-the act of getting drunk. ${ }^{34}$

Thus, Justice White adopted a status crimes theory that would protect homeless people from prosecution for public intoxication. Unlike the dissenting Justices, however, he was not willing to extend this protection to alcoholics who could choose to remain indoors.

Justice White's concurrence is important for several reasons. First, although he upheld Powell's conviction, he and the four dissenting Justices formed a majority that rejected the plurality's narrow construction of Robinson. Second, he recognized that seemingly neutral statutes prohibiting public conduct may have a disproportionate impact on homeless people, who are forced to live in public. Third, Justice White seemed to recognize what Oliver Wendell Holmes, Jr., said long before him, that "a law which punished conduct which would not be blameworthy in the average member of the community would be too severe for that community to bear." ${ }^{\prime 35}$

After Powell, lower courts faced two distinctly different conceptions of the breadth of the Eighth Amendment status crimes

\footnotetext{
33 Id at 549-50 (White concurring).

34 Id at 551.

${ }^{35}$ Oliver Wendell Holmes, Jr., The Common Law 50 (Little, Brown, 1881).
} 
doctrine, neither entirely clear. ${ }^{36}$ The Robinson majority articulated an act test and a culpability test: if a person were punished for a mental state with no act, or if a person were punished for acts she could not avoid, that punishment would be unconstitutionally cruel and unusual. The Powell plurality read the status crimes doctrine as an act-excluding test: if a person were punished for a mental state without an act, that punishment would be unconstitutional; the state, however, could forbid any act, no matter how banal or harmless, without running afoul of the status crimes doctrine.

\section{B. A Critique of the Act/Status Distinction in Powell}

The status crimes doctrine espoused by Justice Marshall on behalf of the four-Justice plurality in Powell would permit cities to prohibit innocent acts of the homeless. However, there are good reasons not to apply Powell's strict, act-excluding test to cases involving homeless people. As a matter of precedent, the Powell plurality opinion does not bind future courts. As a matter of logic, Marshall's act-excluding approach is inconsistent with Robinson. As a matter of practicality, Marshall's test is difficult to apply, and this difficulty limits Powell's persuasiveness in cases involving the homeless.

1. Powell is not binding precedent in homelessness cases.

The final word on homelessness as a status crime is Robinson, not Powell, and Justice Marshall's plurality opinion in the latter case should not be used to empower states to punish status crimes of the homeless. Recall that Justice White concurred in the result of Powell, but agreed with the dissenting Justices that Robinson protected both status and actions that the defendant could not avoid, such as appearing in public if the defendant were homeless. ${ }^{37}$ Justice White explicitly said that the statute in question would be unconstitutional if applied to homeless people. ${ }^{38}$ Because a majority of the Justices in Powell would have afforded protection to actions attendant to homelessness, that

${ }^{35}$ See, for example, Watson $v$ United States, 439 F2d 442, 451 (DC Cir 1970) (“[T]he Supreme Court in Powell has left this matter of criminal responsibility, as affected by the Eighth Amendment, in a posture which is, at best, obscure.").

${ }^{37}$ Powell, 392 US at 551 (White concurring).

3s Id. 
case, at the very least, should not be read to remove the protection afforded in Robinson.

In narrowing Robinson, Justice Marshall ignored the culpability branch of the Robinson definition of status crimes, ${ }^{39}$ holding instead that the Eighth Amendment protected no status that involved an act, no matter how benign or coerced. ${ }^{40}$ This interpretation ignores Robinson's facts. Robinson had engaged in a behavior that society has an interest in preventing: he had abused narcotics. If the act-excluding test were the only inquiry, Robinson could have been imprisoned for having acted to cause his status.

The Powell approach threatens to eviscerate the status crimes doctrine itself. Because almost every status manifests itself in some action, the state could punish a status by simply punishing the acts inherent to it. Cities could, consistent with the Powell plurality view, punish the flu by criminalizing sneezing, punish sleepiness by prohibiting yawning, or punish homelessness and hunger by proscribing eating in public. Powell's departure, as articulated in the plurality opinion, eviscerates the Robinson doctrine, leaving behind the mere form of words.

Robinson's mandate, the dissenting Justices in Powell rightly explained, was not so ephemeral. Rather, under Robinson, it is not enough that a court is able to proscribe some action as a pretext for prohibiting status. The dissent said it was cruel and unusual to punish an action that the defendant was completely unable to avoid:

Robinson stands upon a principle which, despite its subtlety, must be simply stated and respectfully applied because it is the foundation of individual liberty and the cornerstone of the relations between a civilized state and its citizens: Criminal penalties may not be inflicted upon a person for being in a condition he is powerless to change. ${ }^{41}$

Powell dealt with a statute that criminalized the status of being drunk in public. The dissent's argument for protection of statusinherent actions is even more compelling where the status is homelessness, not drunkenness, and the actor did not create her

\footnotetext{
S9 See text accompanying notes 26-27.

40 Powell, 392 US at 533.

41 Id at 567 (Fortas dissenting).
} 
own status. Individuals choose to drink or to use drugs, but few people choose to be homeless. ${ }^{42}$

2. Powell's act-excluding test is logically flawed and difficult to apply.

Powell's dissenting Justices have the better reading of Robinson..$^{43}$ After discussing how drug addiction is properly considered an illness, one that could be contracted innocently or involuntarily, the Robinson Court held that "a state law which imprisons a person thus afflicted as a criminal" in the absence of a culpable act inflicts a cruel and unusual punishment. ${ }^{44}$ The reasoning of the Court hinges as much on Robinson's powerlessness to change his situation (because of illness) as on the fact that he had not committed an act.

The text of Robinson aside, courts considering the status crimes doctrine should not ascribe much persuasive authority to the Powell opinion because it is logically problematic, both internally and in its implications. Although the act-excluding test seems analytically clear, it is in practice very convoluted, especially as applied in homelessness cases. In a philosophical sense, almost all status is defined in reference to conduct: to be is to do. For example, people are not born bartenders; they become bartenders by tending bars. With the exception of such biologically determined factors as sex or race, we are defined by reference to what we do, constantly involved in the act of self-definition, of status creation. ${ }^{45}$ Some who might legitimately claim status pro-

42 See Pottinger $v$ City of Miami, 810 F Supp 1551, 1557 (S D Fla 1992), remanded on limited grounds, 40 F3d 1155 (11th Cir 1994) (noting expert testimony that homeless people "rarely, if ever, choose to become homeless," and that most become homeless after financial misfortune or illness).

${ }^{43}$ See Wayne R. LaFave anả Austin W. Scott, Jr., I Substantive Criminal Law § 2.14 at $257 \mathrm{n} 139$ (West, 1986) (calling the act-excluding approach of the Powell plurality a "questionable assumption" about Robinson).

" Robinson, 370 US at 667 (emphasis added).

45 The cases have addressed and criticized this distinction in various ways. In Powell, Justice Marshall called unchosen characteristics "statuses" and chosen ones "conditions," although this discussion was in dicta. Powell, 392 US at 533. In his concurring opinion in that case, Justice White dismissed Justice Marshall's distinction, saying that it did not advance analysis of the case. Id at $550 \mathrm{n} 2$ (White concurring). The district court in Joyce $v$ City and County of San Francisco, 846 F Supp 843, 857-58 (N D Cal 1994), said that "conditions," because they had been caused by the actor, deserved no protection under the status crimes doctrine, and that homelessness was more like a condition than a status. The Joyce court failed to explain how homeless persons cause their status any more than Robinson (by sticking needles in his arms) caused himself to become a drug addict. Because Robinson plainly involved a condition that was protected as a status, Justice 
tection, such as Robinson, a drug addict, create their own status. The homeless have a stronger case for status protection because their status is often created by circumstances beyond their control, such as a serious illness.

Because nearly all status is based in action, drawing a line between the two becomes a murky inquiry into the nexus between status and conduct. The inquiry quickly breaks down into a question of whether the status was sufficiently far removed from the act to maintain its Eighth Amendment protection, or it becomes a tautological question of whether the acts are bad in themselves. In either case, the simple test of actus reus quickly becomes a quagmire.

To say that narcotic addiction is a status that does not involve action is to look at too narrow a time frame and to ignore the prior drug use that created the addiction. Justices White and Clark identified this problem in their dissents in Robinson. Justice Clark pointed out that to find that Robinson was addicted, the lower court required a finding that he had habitually used drugs, not that he was merely predisposed toward their use. ${ }^{46}$ Powell's proximity approach may reflect little more than the judges' predispositions in the different cases, resulting in a retrospective look for prior action in some instances (such as Powell's drinking in the hours before his arrest) and not in others (such as Robinson's systematic drug use as recently as three days before his arrest). ${ }^{47}$ Temporal proximity is too fragile and subtle a distinction to support so important a liberty interest as freedom from cruel and unusual punishment.

The temporal nexus approach suggested by the Powell plurality is also fatally confusing in homelessness cases. For example, how would a court determine what financial decisions of poor people are sufficiently culpable "acts" such that society can then

White appears to be right: this distinction does not aid in analysis of the cases. This Comment therefore disregards (as did the Robinson Court) the distinction between "status" and "condition."

${ }^{46}$ Robinson, 370 US at 680 (Clark dissenting). See also id at 686 (White dissenting) ("I do not consider appellant's conviction to be a punishment for having an illness or for simply being in some status or condition, but rather a conviction for the regular, repeated or habitual use of narcotics immediately prior to his arrest ....").

${ }^{47}$ One might profitably wonder as well why acts that create status deserve more protection than acts that status necessitates. For example, should Robinson not be held responsible for his repeated acts of shooting up (acts that create his status as an addict ex ante) if homeless people are held responsible for acts such as urinating in a public place (acts that are necessitated by their status as homeless ex post)? Neither Robinson nor Powell offers a reason why acts giving rise to status deserve more protection than acts compelled by status. 
punish homelessness itself? On what basis could a court decide whether sleeping was an act or a status? Is drug addiction a typical status or is it the boundary between acts and act-induced status? The Powell plurality's act-excluding test raises more questions than it answers, especially in homelessness cases.

Another logical problem with Marshall's conception of status, as Justice White suggests in his concurrence, is that it is inconsistent to say that the state may not punish compulsion, but that it may punish resignation to such compulsion. White said that this was like forbidding criminal punishment for having epilepsy, but permitting punishment for having seizures. ${ }^{48}$ This claim may overstate some cases, but it has more bite for nonculpable homeless people than for alcoholics or drug abusers who create their own status. If it is cruel to punish people for the status of being homeless, it is just as cruel to punish the harmless acts this status necessitates, such as sleeping or eating in public.

Punishing homelessness is cruel because homeless people are unable to change their position and often unable to comply with the law even if they wanted. The fact that a city punishes a homeless person for her actions rather than merely outlawing the status of homelessness does not make the punishment any less cruel. Two facts make this argument even more compelling. First, in many of the recent homelessness cases, because of a lack of public shelter, eating facilities, or bathrooms, the plaintiffs would die if they did not violate the law. Second, the acts in many of these cases are socially harmless, such as lying down in a park. These facts argue forcefully for protecting status-attendant acts of homeless people more than the acts of chronic alcoholics and drug addicts.

The final logical inconsistency in the plurality decision in Powell is that it ignores the difference between a difficult choice and no choice at all. This is really the crux of the issue: how can the Court protect innocent statuses and attendant acts without opening the floodgates to frivolous status claims and expanding protection to all acts attending that status? ${ }^{49}$

43 Powell, 392 US at 548 (White concurring).

' See id at 534 ("If Leroy Powell cannot be convicted of public intoxication, it is difficult to see how a State can convict an individual for murder, if that individual, while exhibiting normal behavior in all other respects, suffers from a 'compulsion' to kill ...."); id at 545 (Black concurring) (protecting Powell would create a rule that could not be limited); Joyce, $846 \mathrm{~F} \mathrm{Supp} \mathrm{at} 858$ (protecting homelessness as a status would require constitutional protection for any condition over which the defendant had no control). 
A broad reading of Robinson might open the floodgates to such absurd and counterproductive applications as protection of drug use. However, the status crimes doctrine needs a more sensible limiting principle than the one the Powell plurality suggests. Absent such a principle, courts extending the status crimes doctrine would do so at some risk. As Part II of this Comment demonstrates, it should be possible to extend limited protection to do-or-die, life-sustaining acts of the homeless without opening the status crimes door to everyone with a propensity to break the law. Although Powell probably limits the applicability of the status crimes doctrine in many cases, Justice White's concurrence (at least) prevents this narrowing in homelessness cases.

This Section has suggested that the Powell plurality's attempt to narrow the status crimes doctrine is not binding authority in homelessness cases because Justice White's concurrence would exempt homeless people. In addition, the plurality's actexcluding test misreads Robinson and is logically inconsistent. Homelessness is certainly more of a status than drug addiction, which Robinson protects. A survey of the way lower courts have applied the status crimes doctrine to recent homelessness cases supports this analysis and reflects a limited rejection of Powell.

\section{Recent Eighth Amendment Challenges to Anti-Homelessness Statutes}

Following the Supreme Court's decisions in Robinson and Powell, lower courts across the country overturned vagrancy laws prohibiting joblessness and purposelessness as unconstitutionally based on status, thus extending Eighth Amendment protection to many homeless people. ${ }^{50}$ However, the courts' liberalization of the law was only a temporary setback for some cities. In response to alarming and rapid increases in the number of homeless people in urban areas, many cities and states enacted aggressive laws targeting the dispossessed. These laws prohibited acts such

so See, for example, Headley $v$ Selkowitz, 171 S2d 368, 370 (Fla 1965) (holding that a vagrancy statute, even if otherwise valid on its face, should not be applied to vagrants when their status is not due to choice or intentional conduct); Wheeler $v$ Goodman, $306 \mathrm{~F}$ Supp 58, 64 (W D NC 1969), vacated on other grounds, 401 US 987 (1971) (determining that vagrancy law was unconstitutional because it punished status); Alegata $v$ Commonwealth, 353 Mass 287, 231 NE2d 201, 207 (1967) (deciding that idleness and poverty are not criminal). For a more comprehensive list of cases, see Pottinger $v$ City of Miami, $810 \mathrm{~F}$ Supp 1551, 1562 (S D Fla 1992), remanded on limited grounds, 40 F3d 1155 (11th Cir 1994). 
as lying down, sleeping, standing, or sitting in public. ${ }^{51}$ In one case, police arrested sixty-three homeless people for littering, jaywalking, destroying vegetation, and violating the fire code; the police handcuffed the accused, chained them to benches, numbered them with a black marker, and held them for six hours. ${ }^{52}$ The cities in question merely changed their vagrancy statutes from general prohibitions of status to prohibitions of acts tied to the status of homelessness, such as sleeping in public places. ${ }^{53}$

In at least five cases people have sued these cities, claiming in part that their Eighth Amendment liberty from cruel and unusual punishment had been infringed because they were arrested for their homeless status. ${ }^{54}$ They have essentially argued that punishing life-sustaining acts is little more than punishing homelessness itself, regardless of the subterfuges that lawmakers employ. This controversy has revived the unsettled issue of defining status crimes and has highlighted the inconsistency between Robinson and Powell.

In Pottinger $v$ City of Miami, the first of these cases to explicitly extend Eighth Amendment protection to homeless people, the plaintiffs filed a class action suit on behalf of themselves and approximately six thousand other homeless people in Miami under 42 USC $\S 1983$, seeking to enjoin the City from arresting homeless people for inoffensive public conduct. ${ }^{55}$ The district court enjoined Miami from enforcing laws that prohibit acts in-

51 See, for example, Pottinger, 810 F Supp at 1561.

${ }_{52}$ See Tobe $v$ City of Santa Ana, 9 Cal 4th 1069, 40 Cal Rptr 2d 402, 408 (1995).

$\omega 3$ See, for example, Pottinger, $810 \mathrm{~F}$ Supp at 1559-60, which describes some of the statutes Miami used to punish homelessness:

The records show that the City arrested homeless individuals for standing, sleeping or sitting on sidewalks in violation of City of Miami Code $\$ 37-53.1$ (prohibiting obstruction of sidewalks); for sleeping on benches, sidewalks or in parks in violation of Miami Code § 37-63 (prohibiting sleeping in public); for sleeping in the park in violation of Miami Code $\S 38-3$ (prohibiting being in the park after hours); for loitering and prowling in violation of Florida Statutes $\S 856.021$ and Miami Code $\S \S 37-34$ and 35; and for sleeping, sitting or standing in public buildings in violation of Florida Statutes $\$ \S 810.08$ and .09 (prohibiting trespassing).

54 Pottinger, 810 F Supp 1551; Tobe, $40 \mathrm{Cal}$ Rptr 2d 402; Church $v$ City of Huntsville, 1993 US Dist LEXIS 20429 (N D Ala), vacated on other grounds, 30 F3d 1332 (11th Cir 1994); Joyce $v$ City and County of San Francisco, 846 F Supp 843 (N D Cal 1994); Johnson $v$ City of Dallas, 860 F Supp 344 (N D Tex 1994).

$\approx 810$ F Supp 1551, 1553-54 (S D Fla 1992), remanded on limited grounds, 40 F3d 1155 (11th Cir 1994). 
herent in homelessness, such as sleeping in public places, lying down, or sitting. ${ }^{56}$

Pottinger focused on the status of homeless people and the nonvolitional nature of their inoffensive acts, and held that the dispossessed have no choice but to be homeless and to eat and sleep in public. ${ }^{57}$ The court read Robinson and Powell as a constitutional ban on statutes criminalizing acts from which people cannot abstain. ${ }^{58}$ In this respect it distinguished Powell as dealing with a choice to drink and appear in public, acts from which the defendant could have refrained. ${ }^{59}$ The court followed Justice White's concurrence in Powell, holding that acts necessitated by the status of homelessness can be no more criminal than the status of homelessness itself. ${ }^{60}$ Justice White concurred in upholding Powell's conviction because he found that Powell had a choice: Powell could have made arrangements to be home instead of on the streets when he was drunk. Justice White said that if Powell were forced to be in public, then his conviction would be unconstitutional. The Pottinger court pointed out that homeless people are forced to be in public. ${ }^{61}$ Although the court recognized that the plaintiffs' acts would not be protected under Powell's strict, act-excluding test, it distinguished the facts of that case and held that the lack of choice inherent in the status of homelessness was sufficient to extend the Eighth Amendment protections articulated in Robinson. ${ }^{62}$

56 Id at 1584.

57 Id at 1554.

ss Id at 1562-63.

s9 Id.

60 See Powell, 392 US at 548 (White concurring) ("If it cannot be a crime to have an irresistible compulsion to use narcotics [citing Robinson], I do not see how it can constitutionally be a crime to yield to such a compulsion."). This argument in Powell seems to be the bottom of the slippery slope about which White warned in Robinson.

61 "For plaintiffs, resisting the need to eat, sleep or engage in other life-sustaining activities is impossible. Avoiding public places when engaging in this otherwise innocent conduct is also impossible.... As long as the homeless plaintiffs do not have a single place where they can lawfully be, the challenged ordinances, as applied to them, effectively punish them for something for which they may not be convicted under the eighth amendment-sleeping, eating and other innocent conduct." Pottinger, 810 F Supp at 1565. Note the parallel construction in Justice White's concurrence in Powell: "For some of these alcoholics I would think a showing could be made that resisting drunkenness is impossible and that avoiding public places when intoxicated is also impossible. As applied to them this statute is in effect a law which bans a single act for which they may not be convicted under the Eighth Amendment-the act of getting drunk." 392 US at 551 (White concurring).

${ }^{62}$ Pottinger, 810 F Supp at 1563-64. 
The Pottinger analysis extends Eighth Amendment protection to acts, not merely status. The court in Pottinger used the fact that the actor had no choice but to violate the law to distinguish that case from Powell and to bypass Powell's act-excluding test. ${ }^{63}$ Powell involved a chronic alcoholic who had the choice to stay in his house. The plaintiffs in Pottinger could not choose to conduct these acts in private because they had no homes.

Three subsequent cases have employed the reasoning in Pottinger to protect the acts of homeless people. In Johnson $v$ City of Dallas, a federal district court temporarily enjoined enforcement of a Dallas ordinance prohibiting sleeping in public. ${ }^{64}$ The court held that the ordinance was unconstitutional as applied to homeless people, but declined to enjoin enforcement of statutes prohibiting removal of trash from trash cans, coercive solicitation, and trespassing. ${ }^{65}$ The Johnson court reasoned that the status of "being" in itself could not be criminalized under Robinson, and because being does not exist without sleeping, the city could not punish sleeping. ${ }^{66}$ Importantly, the court in Johnson noted that the city could enforce the ordinance if it offered enough shelter for all the city's homeless people to sleep:

It seems that that situation would put one in the position of a Mr. Powell, who could be punished for conduct not inextricably intertwined in a status. But as long as homeless persons must live in public, their sleeping may not be constitutionally criminalized. ${ }^{67}$

In Church $v$ City of Huntsville, the district court enjoined Huntsville, Alabama from isolating or removing homeless people from the streets of the city because of their status ${ }^{68}$ and from

¿3 Id at 1563.

64 860 F Supp 344, 350-51 (N D Tex 1994).

6. Id at $349-50$.

Es Id at 350. This odd ontological argument of the Johnson court adds little to the Eighth Amendment discussion. People are often "being" without sleeping (especially in law schools). Further, replace "being" with "addiction" and "sleeping" with "drug use," and the syllogism legalizes drug use.

67 Id at 351 .

es 1993 US Dist LEXIS 20429, *1-2, vacated on other grounds, 30 F3d 1332 (11th Cir 1994). The court reasoned:

While the City of Huntsville is under no constitutional duty to address the problem of its homeless citizens, it is under a constitutional duty not to discriminate against them solely because of their status as such.

Id at *6-7. 
harassing homeless people for "walking, talking, sleeping, or gathering in parks. ${ }^{\text {"69 }}$ Huntsville had repeatedly expelled homeless people from its city limits and had a severe public housing problem. ${ }^{70}$

In Tobe $v$ City of Santa Ana, a California state court held that a vagrancy statute thinly veiled as a "camping ordinance" violated the Eighth Amendment. ${ }^{71}$ The court's reasoning was similar to that in Pottinger. In Tobe, Santa Ana's internal memoranda revealed an undeclared war on homelessness beginning in $1988 .^{72}$ The city had shelter for approximately 332 of its 3,000 homeless residents, and it chose to accommodate the other 2,600plus of them by destroying their property, discouraging their food providers from serving them, turning park sprinklers on them, and, eventually, arresting them. ${ }^{73}$

To further its war effort, the city passed an ordinance forbidding camping and public storage of personal property. ${ }^{74}$ The ordinance defined camping as "to pitch or occupy camp facilities; to live temporarily in a camp facility or outdoors; to use camp paraphernalia..75 The Tobe court held that the ordinance was a cruel and unusual punishment of status. ${ }^{76}$ The court's emphasis on the involuntary nature of the status of homelessness echoed similar reasoning in Pottinger and Robinson. ${ }^{77}$ In a loosely reasoned opinion, the court held that Santa Ana's camping statute was akin to punishing mental illness, a step the Robinson Court said was beyond the Eighth Amendment pale. ${ }^{78}$ The Robinson majority predicted that the prospect of a community punishing

69 Id at $* 2$.

70 Id at *4-5. The Eleventh Circuit vacated the district court's ruling on other grounds. Church $v$ City of Huntsville, 30 F3d 1332, 1343-44 (11th Cir 1994). The plaintiffs were unable to show a formal municipal policy to deprive them of their constitutional rights, a required element of an action against a municipality under 42 USC $\S 1983$. See Monell v Department of Social Services, 436 US 658, 691 (1978) (requiring local custom or policy of deprivation of constitutional rights for local governments to be liable in $\S 1983$ suits).

${ }^{11} 22$ Cal App 4th 228, 27 Cal Rptr 2d 386, 393 (1994), rev'd 9 Cal 4th 1069, 40 Cal Rptr 2d 402 (1995).

${ }^{72}$ Tobe, 27 Cal Rptr $2 d$ at $387-88$.

73 Id at 387-89. Perhaps most alarming was the fact that this was the city's official policy, as reflected by a series of memoranda among various city officials.

34 Id at 389.

75 Id at $389 \mathrm{n} 3$ (emphasis added).

76 Id at 393 .

77 Id at 393-94. Compare Robinson, 370 US at 667; Pottinger, 810 F Supp at 1562-63.

78 $27 \mathrm{Cal}$ Rptr $2 \mathrm{~d}$ at 393. 
mental illness was "unlikely."" The Tobe court rejoined:

Unlikely maybe, but that is what Santa Ana has done. Many of the homeless are mentally ill. They may not be punished for that or their homeless condition. Homelessness, like illness and addiction, is a status not subject to the reach of the criminal law; and that is true even if it involves conduct of an involuntary or necessary nature . . . ${ }^{80}$

Thus, the Tobe court apparently adopted the Pottinger strategy of extending protection to acts that a person must perform because of her status.

Recently, the California Supreme Court reversed Tobe, holding that Powell makes clear that acts are not status. ${ }^{81}$ On appeal, the court held that, because homeless people had some control over their own homelessness, homelessness was not a protected status. ${ }^{82}$ Further, the court held that acts were not protected by the status crimes doctrine after the plurality opinion in Powell..$^{83}$ California's highest court did, however, offer some reassurance for homeless people: a senior deputy district attorney "expressed his opinion during oral argument" that a necessity defense might be available to "truly homeless" persons and that the city would exercise prosecutorial discretion in arresting homeless people. ${ }^{84}$

Finally, the court in Joyce $v$ City and County of San Francisco rejected the reasoning of the Pottinger line of cases. ${ }^{85}$ In Joyce, a class of homeless plaintiffs brought suit to enjoin San Francisco from conducting parts of its "Matrix Program" for dealing with the homeless. ${ }^{86}$ Although the plaintiffs supported many parts of the city's "Matrix" plan, they sought to enjoin the city from penalizing "life sustaining activities" of the homeless. ${ }^{87}$ The "Matrix" plan presented a comprehensive strategy for dealing with homelessness, complete with ample emergency shelter ${ }^{88}$ a

79 Robinson, 370 US at 666.

6obe, 27 Cal Rptr 2 d at 393.

*1 Tobe $v$ City of Santa Ana, 9 Cal 4th 1069, 40 Cal Rptr 2d 402, 423-34 (1995).

$\$ 2$ Id.

$\$ 3$ Id.

84 Id at $412 \mathrm{n} 8$.

s5 846 F Supp 843 (N D Cal 1994).

85 Id at 845 .

67 Id at 846 .

28 The city had both a long-term housing program and an emergency program to house those not in the long-term plan. The city offered evidence that of 3,820 referral slips 
nondiscrimination policy, ${ }^{89}$ an information campaign to inform homeless people of available services, ${ }^{90}$ and a generous public assistance program. ${ }^{91}$

Faithfully applying the plurality analysis from Powell, the Joyce court denied the homeless plaintiffs an injunction against enforcement of laws prohibiting life-sustaining activities. ${ }^{92}$ The Joyce court forthrightly addressed the act/status distinction, holding that the Court in Powell had explicitly refused to extend Eighth Amendment protection to acts attendant to a status, such as the drinking endemic to Powell's chronic alcoholism. ${ }^{93}$ The court noted that Powell was convicted for exactly those actions and that the Supreme Court upheld his conviction. ${ }^{94}$ The plaintiffs in Joyce contended that Justice White's concurrence in Powell signaled a five-Justice majority for the proposition that nonvolitional, unchosen actions attendant to status deserved protection. ${ }^{95}$ The Joyce court rejected this argument, however, reasoning that Justice White's concurrence was dicta, ${ }^{96}$ and it refused to espouse such a "revolutionary doctrine of constitutional law" based on speculation on how Justice White might vote on different facts. ${ }^{97}$

In addition to denying protection for life-sustaining activities, the court in Joyce refused even to recognize homelessness as a status. ${ }^{98}$ The court said that although status was difficult to define, "the involuntariness of the acquisition of that quality (in-

(redeemable for shelter) that were offered to men, only 1,866 were taken, and only 678 were actually redeemed for shelter. Women were referred to a separate shelter, and the city provided transportation. Id at 848 . This evidence was countered at trial by plaintiffs' claim that on average 600 people were turned away from homeless shelters each night in the Bay Area. Id at 849.

89 The nondiscrimination policy provided: "All persons have the right to use the public streets and places so long as they are not engaged in specific criminal activity. Factors such as race, sex, sexual preference, age, dress, unusual or disheveled or impoverished appearance do not alone justify enforcement action." Id at 847 .

9 Id at 847-48.

91 Homeless people in San Francisco were entitled to greater benefits than almost anywhere else in California: a maximum of $\$ 345$ per month and as much as $\$ 109$ per month in food stamps. Id at 848.

${ }_{92}$ Id at $852-53,857-58$.

93 Id at 857.

os Id.

9s Id. Recall Justice White's suggestion that had Powell been forced by homelessness to be in public, he would have deserved Eighth Amendment protection because he would then have been punished solely for drinking, an otherwise lawful activity. Powell, 392 US at 551 (White concurring). See also text accompanying note 34 .

${ }_{96}$ Joyce, $846 \mathrm{~F}$ Supp at 857.

${ }^{97}$ Id at 857-58, quoting Powell, 392 US at 537 (Blackmun concurring).

98 Joyce, 846 F Supp at 857. 
cluding the presence or not of that characteristic at birth), and the degree to which an individual has control over that characteristic" might be signals as to whether the trait was a status or a "condition." The court posited that a status is acquired involuntarily and might include such factors as age, race, national origin, gender, and illness, whereas a condition is acquired by some act. ${ }^{100}$ Additionally, the court reasoned that an actor may change her condition more easily than her status. ${ }^{101}$ The court then suggested that the Supreme Court based its ruling in Robinson on the fact that one might acquire a drug addiction involuntarily at birth, a possibility the Joyce court did not see in the homelessness context. ${ }^{102}$ The court finally explained that it found Justice White's dissent in Robinson persuasive, expressing concern that if it extended status protection to homelessness, it would likely have to extend the same protection to acts necessitated by homelessness. ${ }^{103}$ Because it chose not to recognize homelessness as a status, the Joyce court refused to extend that protection to life-sustaining acts.

The Joyce court's scholarly and well reasoned opinion misunderstands the status crimes doctrine in at least one respect. The Joyce court's distinction between a condition and a status was not a product of Robinson, and Powell only alluded to it. ${ }^{104}$ The Joyce court's assertion that a status that one creates cannot be protected flies directly in the face of Robinson, in which the defendant created his addiction through drug use. Indeed, the status of homelessness may be acquired from birth just as easily as drug addiction. Thousands of children are born into abject poverty or homelessness each year. ${ }^{105}$ Certainly if a self-created status such as drug addiction deserves protection, homelessness must as well. Nevertheless, fidelity to the plurality decision in Powell probably does dictate the outcome in Joyce: these homeless plaintiffs' acts are not protected under an act-excluding definition of status crimes. In Powell, Justice Marshall created a

99 Id (citations omitted). For a related discussion of Powell's treatment of self-created status, see note 45 .

${ }^{100}$ Joyce, 846 F Supp at 857-58.

101 Id.

102 Id, citing Robinson, 370 US at 665-69 \& $\mathbf{n} 9$.

103 Joyce, 846 F Supp at 858, citing Robinson, 370 US at 688 (White dissenting).

104 Powell, 392 US at 533.

105 See, for example, A Time of Peril, Christian Sci Monitor 18 (Apr 14, 1994) (editorial) (citing a 1994 Carnegie Corporation report estimating that one in four children is born into poverty). 
single-tier inquiry: if an act is involved in the proscribed crime, there is no protected status.

In the Pottinger line of cases, the defendants engaged in acts, and thus were not protected under the Powell regime. Perhaps out of deference to the Supreme Court, these cases attempted to distinguish Powell on its facts instead of criticizing its reasoning or limiting its reach. Although the plaintiffs in Pottinger and its progeny all won lower court battles, these decisions are vulnerable on appeal because they depend on being factually distinguishable from Powell. This is aptly demonstrated in the Tobe case, which the Supreme Court of California reversed on appeal, following the reasoning of Joyce. ${ }^{106}$ However, as discussed in Section B above, Justice White's pivotal concurrence demands that Powell not control homelessness cases, so distinguishing Powell should be unnecessary.

The disagreement among lower courts about how the Supreme Court defines status crimes suggests that the current thinking about the doctrine is insufficient and that courts need either a clearer definition or an alternative theory. The diverging outcomes demonstrate some of the tension between the too-strict option of applying Powell as a limiting principle for status crimes and the too-lenient option of rejecting Powell without an alternative limiting principle. ${ }^{107}$ If the courts followed Robinson and the five-justice majority in Powell, they would protect the acts of homeless people who had no choice but to conduct their lives in public.

Part I has suggested that the Powell dissenters and Justice White have charted a better course for homelessness cases than that taken by the Powell plurality. Perhaps Justice White's specific mention of homeless people is itself a limiting principle in these cases: the act-excluding test applies to all statutes, except those applied to acts of the homeless. Part II suggests a better approach for Eighth Amendment protection of the homeless. Statutes that prohibit actions in do-or-die situations essentially mandate death, which is per se cruel and unusual. Using this

106 Tobe, 40 Cal Rptr 2d at 423.

107 Powell's narrowing construction is an attempt (probably an overzealous one) to limit the status crimes doctrine. See Powell, 392 US at 533 ("[U]nless Robinson is so viewed it is difficult to see any limiting principle that would serve to prevent this Court from becoming, under the aegis of the Cruel and Unusual Punishment Clause, the ultimate arbiter of the standards of criminal responsibility, in diverse areas of the criminal law, throughout the country."). 
approach, courts can apply the Eighth Amendment directly, making the status crimes designation superfluous.

\section{Eighth AMENDMENT CRUEL AND UNUSUAL PUNISHMENT IN Do-OR-DIE SiTUATIONS}

\section{A. The Proposed Standard}

Justice White noted in his Powell concurrence that it would be unconstitutional to punish a homeless person for being drunk in public. Similarly, a statute prohibiting eating in a public place renders a homeless person punishable for an innocent act. But unlike Justice White's drunk, a homeless person can suffer serious bodily injury, even death, if she complies with the law (if it is even possible for her to comply). Nevertheless, the act-excluding status crimes approach of the Joyce court, dictated by Powell, would permit cities to proscribe such life-sustaining conduct.

Enforcing such a statute in a do-or-die situation is manifestly cruel and unusual, and courts should not hesitate to strike the statute as such. Courts should (of course) forbid the punishment of status, but they should also require cities to comport their prohibitions of acts to the Eighth Amendment. The Eighth Amendment regulates the types of punishments courts may impose, but it also limits the conduct legislatures may criminalize. ${ }^{108} \mathrm{~A}$ court should invalidate as cruel and unusual any ordinance that prohibits acts that people have absolutely no choice but to do. In this context, "no choice" means that a homeless person must perform the proscribed act in order to live and that the person knows of no less socially harmful way to perform the act. Although the homeless person technically "chooses" to stay alive, this choice is hardly meaningful: choosing death is no choice at all.

Because homeless people often need to act to save their lives in ways that violate local ordinances, they act not in culpable but in necessary ways. At common law, a homeless person could defend these actions by asserting the defense of necessity: she had a valid justification for her actions if she reasonably believed (1) that she was in danger of harm, (2) that the only way to avoid this harm was by breaking the law, and (3) that the harm that would be caused by breaking the law was less serious than the harm she was trying to avoid. ${ }^{109}$

103 LaFave and Scott, 1 Substantive Criminal Law $\$ 2.14$ at 255 (cited in note 43).

${ }^{109}$ See Joshua Dressler, Understanding Criminal Law $\$ 22.02$ at 250-51 (Matthew 
Necessity was the idea driving Justice White's concurrence in Powell. Justice White disagreed with the plurality's act-excluding reading of Robinson because if Powell had been homeless, being in public would have been necessary. Powell could have been nowhere else. ${ }^{110}$ The dissenting Justices agreed that punishing acts necessarily tied to status violated the Eighth Amendment because status was essentially part of the criminal act:

[A] person may not be punished if the condition essential to constitute the defined crime is part of the pattern of his disease and is occasioned by a compulsion symptomatic of the disease. ${ }^{111}$

The dissenting Justices defined "necessary" differently than this Comment does. They used the word to mean "symptomatic," where this Comment uses the word to describe actions that are the actor's only alternative to death. ${ }^{112}$ The dissent's definition is so broad that it might include such things as drug use (necessary to drug addiction) or arson (attendant to pyromania) within its sweep. Not all acts symptomatic to status deserve Eighth Amendment protection. Therefore, this Comment proposes an objective test for determining which acts attendant to the status of homelessness are protected. The test is objective in that the court, and not the defendant, decides whether the act was really in response to a do-or-die situation. This Comment suggests a reading of the Eighth Amendment that directly protects do-or-die acts.

This proposal limits itself in two ways, both in its application to statuses other than homelessness and in its application to the

Bender, 1987), citing State v Moe, 174 Wash 303, 24 P2d 638, 640 (1933). The necessity defense is no longer available in states that have adopted the Model Penal Code definition of necessity, which requires that "a legislative purpose to exclude the justification claimed does not otherwise plainly appear." Model Penal Code § 3.02(1)(c). See, for example, State $v$ Morris, 242 NJ Super 532, 577 A2d 852, 856-57 (1990) (laws forbidding prison break evidenced legislative purpose to block necessity defense for escapees claiming poor prison conditions); State $v$ Tate, 102 NJ 64, 505 A2d 941, 944-45 (1986) (drug laws blocked necessity defense where defendant used marijuana to treat spasticity caused by quadriplegia).

${ }^{110}$ Powell, 392 US at 551 (White concurring).

111 Id at 569 (Fortas dissenting).

112 One commentator has suggested that homeless people should have a necessity defense to prosecution under such ordinances. See Comment, "Anti-Homeless" Legislation: Unconstitutional Efforts to Punish the Homeless, 45 U Miami L Rev 417, 452-54 (1990-91). Note, however, that homeless people will rarely get the chance to raise such a defense at trial, because most elect to plead guilty on the spot and secure release, rather than wait in prison for trial. See generally Waxman, 23 Stetson L Rev 467 (cited in note 1). 
acts of the homeless. First, this proposal does not protect conduct simply because a person feels powerless to avoid it or toward which an actor merely feels an overwhelming compulsion. The Eighth Amendment does not protect drug use or other criminal acts that are not life-or-death choices. Courts would have to distinguish between people who faced a difficult or seemingly compelled choice and those who acted because they had no choice at all. The latter would get constitutional protection while the former would not.

Second, this approach would not protect all acts of homeless people. The acts must be necessary consequents of the status (here homelessness) - theft, for example, would not count, because it is possible simultaneously to have no home and to not steal. The same difficult-choice/forced-choice distinction applies here. For example, if there were shelter available in a city, and a homeless person chose not to avail herself of that shelter, she would have to face the possible consequences of violating a prohibition on sleeping in the park. Where a homeless person has a difficult choice to make, she must fully weigh the possible consequences of each option, including criminal sanctions. It is not possible, however, to balance options in this way when the choice is forced, because one will always choose a prohibited, life-sustaining act over death or serious injury. When cities do not provide adequate shelter, homeless people have no choice but to sleep in public places, and it is cruel and unusual to punish such actions.

Another limitation on the doctrine as proposed is that it would not offer constitutional protection for such mundane acts as bathing in public (unless a person's hygiene became a serious threat to her life). Although punishing an act such as bathing seems cruel, the necessity argument is less compelling in these cases because the homeless person does have a choice, admittedly a difficult one. Although it might be unconscionable for a city to punish activities such as bathing, federalism demands that the states and cities be given broad latitude to exercise police powers. ${ }^{113}$ The states' and cities' domains end at the Constitution,

113 As the Johnson court noted:

Reasonable minds could, of course, differ over the wisdom of criminalizing the conduct of a hungry man trying to feed himself by foraging through abandoned property in hopes of finding food thrown out by a restaurant or grocery store at the end of the day's business. However, the Court recognizes that it may not impose a kinder and 
however, and the Constitution at a minimum protects do-or-die acts of the homeless.

The do-or-die approach meets the goals of criminal justice, especially deterrence, better than the sharp, act-excluding status protection envisioned in Powell. Punishment of life-sustaining, forced actions is gratuitous because it penalizes people who cannot be deterred. People will always choose to sleep in a public place, with the possibility of a criminal sanction, over the alternative of not sleeping. Furthermore, from a culpability perspective, these forced acts are not morally blameworthy when done to preserve life. Indeed, the lack of moral culpability was one rationale underlying the necessity defense at common law. ${ }^{114}$ Since the necessity defense is practically unavailable to homeless people ${ }^{115}$ this proposal acts as a surrogate to protect morally blameless conduct from criminal sanction.

One of the most persuasive arguments against protecting conduct under the Eighth Amendment has been that attempts to limit such a doctrine would prove ineffectual, and soon criminals would seek protection for such acts as drug use. ${ }^{116}$ Arguably, drug use necessarily attends drug addiction, a protected status under Robinson. But this objection ignores the distinction made above: the decision to use drugs is a difficult choice, but a choice nonetheless, for an addict. Although the court cannot punish the latent addiction or the craving for drugs, it could punish actual drug use under the standard proposed here. ${ }^{117}$ Society assumes

gentler approach to the City's means of dealing with such conduct. Instead, this call is left to the democratic process.

860 F Supp at $350 \mathrm{n}$ 5. See also Powell, 392 US at 535-36 (Common law criminal doctrines provide tools for constant adjustment of criminal law, and this process of adjustment is the province of the states.). Note also that chosen acts may be protected under other doctrines, such as excuses, defenses or justifications, such as the lesser evil doctrine. This Comment addresses only Eighth Amendment cruel and unusual punishment challenges.

114 Some cases have suggested that where acts are forced and not chosen, there is no actus reus at all. See, for example, Martin $v$ State, 31 Ala App 334, 17 S2d 427, 427 (1944) (defendant carried onto the street and arrested for public drunkenness was entitled to acquittal). The question of whether a forced choice involves mens rea is irrelevant to this inquiry. See Powell, 392 US at 535 (Justice Marshall explaining that the Court has never articulated a general constitutional requirement of mens rea).

115 See note 112.

116 See Powell, 392 US at 533; Joyce, 846 F Supp at 858. See also note 107 and accompanying text.

117 Commentators have suggested that the volitional language of Robinson mandates protection for "involuntary manifestations" of protected status. Comment, $45 \mathrm{U}$ Miami L 
that addicts have a choice whether to use drugs, even in the face of seemingly irresistible compulsion. This faith in their willpower may seem misplaced, but it was a core principle of the common law, which demanded that compulsions and predispositions not be punished without more, because people could choose not to act on them, no matter how irresistible they seemed. ${ }^{118}$

Of course, protecting acts under the Eighth Amendment is not simple. The inquiry outlined above will involve difficult determinations of what decisions are actually "choiceless," especially where actions seem irresistible, but are not actually forced. For example, imagine a homeless person who has the choice to sleep in a shelter, but chooses not to because of a valid fear that the shelters are too dangerous; or consider a homeless husband and wife who choose to sleep in a park because the only shelters available are segregated by sex. Although there will be difficult cases, courts should be able to meaningfully distinguish between people faced with difficult choices and those with no choice at all. This will sometimes be a difficult distinction to make, but the door-die criterion should simplify the enterprise. Besides, courts make difficult decisions all the time. They should not shy away from a more just standard simply because they might face some hard cases. In addition, the difficulty courts have had in making sense of the current status crimes doctrine indicates that the door-die Eighth Amendment challenge should be much easier to administer than the current morass that is the status crimes doctrine. ${ }^{119}$

\section{B. A Guide for Cities}

Cities may still pursue valid public policy objectives by criminalizing acts attendant to homelessness provided that they offer homeless people choices beyond violation of the law and death. Under the Powell plurality's test, cities would only have to ensure that they did not punish status as status. They would be free to punish status under the guise of punishing acts. That is patently unjust. The standard proposed here offers lawmakers

\footnotetext{
Rev at 441-42 (cited in note 112). It is difficult to see how such an approach could avoid legalizing drug use after Robinson.

${ }_{118}^{118}$ See, for example, People $v$ Zackowitz, 254 NY 192, 172 NE 466, 468 (1930) (Propensity to commit criminal acts can have no bearing on determination of guilt in criminal trials.).

119 See, for example, the opposite interpretations of the status crimes doctrine in Pottinger, 810 F Supp at 1562-63; Joyce, 846 F Supp at 857-58; and text accompanying notes 85-104.
} 
clear guidance and homeless people constitutional protection. If the city or state provides homeless people with choices, such as public shelter or bathrooms, it may constitutionally penalize conduct chosen over the publicly provided alternative.

Cities have an important public health and safety interest in not having homeless people defecating in the streets, but cities must pursue this interest by providing public bathrooms before resorting to criminal sanctions. Cities may employ both, but they may not merely prohibit conduct for which there is no alternative. San Francisco's "Matrix" plan seems to be the model: the plan combines choices with criminal sanctions. ${ }^{120}$ Ideally, by limiting the criminal punishment option, this proposed operation of the Eighth Amendment will result in municipalities providing more services for the homeless. This suggestion provides an incentive for cities and states to get serious about homelessness before they get tough on homeless people. The doctrine should encourage communities to provide services for the homeless without significantly impairing their abilities to pursue valid public policy objectives.

\section{Analysis of Recent Cases Under the Do-Or-Die Standard}

So far, Part II has suggested that plaintiffs in recent homelessness cases might be better off challenging ordinances with a direct Eighth Amendment cruel and unusual punishment theory than with the more artful status crimes doctrine. The Eighth Amendment, at least, provides that cities cannot proscribe life-sustaining acts of homeless people where those people have no other means of survival. This approach is much clearer and more direct than the claim that these ordinances are a pretext for punishing the status of homelessness. In status crimes cases currently on appeal, courts might use the do-or-die criterion as a limiting principle for the status crimes doctrine and protect door-die acts attendant to the status of homelessness. However, future plaintiffs may be better off taking the more direct Eighth Amendment approach.

The direct Eighth Amendment challenge is a stronger foundation for recent cases protecting the homeless. Under the strict Powell standard, many of the actions protected by lower courts are vulnerable on appeal if appellate courts find the acts undis-

${ }^{120}$ See Joyce, 846 F Supp at 846-49 (describing the "Matrix Program"). See also notes 88-91 and accompanying text. 
tinguishable from those involved in Powell. As noted in Part I, homeless plaintiffs probably should win their status crimes claims because courts should not apply Powell's act-excluding test to homeless plaintiffs. ${ }^{121}$ However, there is no guarantee that appellate courts will accord the proper weight to Justice White's concurrence or that they will be willing to limit the reach of Supreme Court precedent. They, like the Joyce court, might choose to apply the Powell plurality test and thus deny protection even to acts that homeless people have no choice but to do. In fact, this is exactly what happened in the Tobe case in the California Supreme Court. ${ }^{122}$ By contrast, the more direct do-or-die approach suggested in this Part offers more reliable protection.

Under the do-or-die standard, the question of whether the ordinance punishes status or an act is irrelevant, because the Eighth Amendment protects any acts that are forced by the threat of death or serious injury. On this analysis, Pottinger, Johnson, Church, ${ }^{123}$ and Tobe all involve protected actions, while Joyce does not.

In Pottinger, the plaintiffs were arrested for lying down, sleeping, standing, sitting, and bathing in public places. ${ }^{124}$ With the exception of bathing, all of these offenses are either forced (one must be either standing, lying down, or sitting) or necessary for life. Punishment of such activities would be unconstitutionally cruel and unusual.

The Johnson plaintiffs, who had nowhere else to go, were forced to sleep in public places; their slumber would be protected do-or-die conduct. In addition, if Dallas does not offer food stamps, soup kitchens, or some other way for homeless people to eat, the Eighth Amendment might also require the city to allow homeless people to subsist on what restaurants or others have discarded. If Dallas continues to close its parks at night, and there is truly no other place for homeless people to be, the Eighth Amendment may prohibit the city from enforcing trespassing ordinances against the homeless as well, at least on public property.

Similarly, in Church, the city of Huntsville could not prohibit walking, sleeping, or gathering in public places because there are

21 See notes 37-41 and accompanying text.

122 Tobe, 40 Cal Rptr $2 d$ at 423.

123 Provided, of course, that the plaintiffs in Church can meet the evidentiary requirements of showing a policy or custom by the city to deprive them of their constitutional rights. See note 70 .

124 Pottinger, 810 F Supp at 1561. 
no private places for homeless people to go. ${ }^{125}$ Likewise, in Tobe, Santa Ana's camping ordinances prohibited such activities as living outdoors ${ }^{126}$ and crawling underneath a blanket to protect against the cold. ${ }^{127}$ The statute would be invalid as applied because in Tobe, as in Pottinger, Johnson, and Church, the city's homeless population exceeded its available shelter.

Joyce, however, is a different case. As discussed previously, ${ }^{128}$ San Francisco had adopted a comprehensive "Matrix" plan for providing services to the homeless. The evidence in that case showed that many homeless people refused available shelter and that the city not only offered public assistance but also conducted an extensive campaign to inform people of available benefits. ${ }^{129}$ Given the availability of alternatives, acts such as trespassing, public inebriation, removal and possession of shopping carts, solicitation, and aggressive panhandling ${ }^{130}$ would not be lifesustaining, forced choices but rather difficult choices about how to make ends meet. ${ }^{131}$ Where homeless people in San Francisco could have chosen to be in shelters, not to steal or be drunk, and not to panhandle, the city could arrest them within its police powers and without violating the Eighth Amendment.

San Francisco is a model for other communities wishing to exercise their police powers with respect to homeless people. By offering public services to the homeless, the city provides them with choices. People faced with viable choices may be criminally punished for making choices the community condemns. But communities may not, consistent with the Eighth Amendment, punish people for being where they must be, nor for doing what they must do, to stay alive.

\section{CONCLUSION}

This Eighth Amendment protection for life-sustaining acts meets the constitutional and common law concerns of the Robinson and Pottinger courts while answering the thoughtful call for a limiting principle for the status crimes doctrine articulated in

${ }^{225}$ Church, 1993 US Dist LEXIS 20429 at $* 5$.

${ }^{126}$ Tobe, 40 Cal Rptr 2d at 407-08 \& n 2.

127 Id.

${ }^{128}$ See text accompanying notes 86-91.

120 Joyce, 846 F Supp at $847-48$.

${ }_{130}$ Id at 846.

${ }^{131}$ Urinating and defecating in public would be protected under the proposed paradigm if plaintiffs could show that there were no facilities where they might have engaged in those life-sustaining activities in private. 
Powell and Joyce. This paradigm will also protect the post-Robinson advances of the 1960s and early 1970s in eradicating archaic vagrancy laws. Robinson protected both status itself and actions attendant to that status that the actor was unable to avoid. Extension of that doctrine to contemporary cases dealing with homelessness will invalidate many statutes that purport to punish acts, but really just punish low status in the community.

This approach is narrow in its scope, so there is little chance of the great opening of the floodgates feared by many. The do-ordie approach limits itself by protecting only choices the actor makes to save her life, so concerns about extending this protection to drug use or theft are misplaced. The proposed doctrine will not protect some benign acts, such as talking, ${ }^{132}$ but it is important to remember that the status crimes doctrine and the Eighth Amendment are not the end of the story. The vagueness doctrine, the right to travel, common law defenses of necessity and lesser evil, and other excuses and justifications may offer supplementary protection for the homeless. Courts should apply these doctrines and a faithful interpretation of the Eighth Amendment aggressively to protect homeless people from any city's improper "war on its own weakest citizens."133

${ }^{132}$ See Church, 1993 US Dist LEXIS 20429 at $* 2$.

${ }^{123}$ Tobe, 27 Cal Rptr 2d at 392 n 4. 